University of Michigan Law School

University of Michigan Law School Scholarship Repository

$5-1977$

\title{
Evaluating Article 2 of the Uniform Commercial Code: A Preliminary Empirical Expedition
}

James J. White

University of Michigan Law School, jjwhite@umich.edu

Follow this and additional works at: https://repository.law.umich.edu/articles

Part of the Commercial Law Commons, Legislation Commons, Litigation Commons, and the State and Local Government Law Commons

\section{Recommended Citation}

White, James J. "Evaluating Article 2 of the Uniform Commercial Code: A Preliminary Empirical Expedition." Mich. L. Rev. 75 (1977): 1262-85.

This Essay is brought to you for free and open access by the Faculty Scholarship at University of Michigan Law School Scholarship Repository. It has been accepted for inclusion in Articles by an authorized administrator of University of Michigan Law School Scholarship Repository. For more information, please contact mlaw.repository@umich.edu. 


\title{
EVALUATING ARTICLE 2 OF THE UNIFORM COMMERCIAL CODE: A PRELIMINARY EMPIRICAL EXPEDITION
}

\author{
James J. White*†
}

The object of this codification of the law with respect to negotiable instruments was to relieve the courts of the duty of citation of conflicting cases and discussion of the discordant views entertained by courts and text writers of the greatest ability upon these questions, and to render certain and unambiguous that which had theretofore been doubtful and obscure, so that the business of the commercial world, largely transacted through the agency of negotiable paper, might be conducted in obedience to a written law emanating from a source whose authority admits of no question. ${ }^{1}$

So wrote Amasa M. Eaton in the pages of this review in 1913. A proponent of commercial law codification, Mr. Eaton was one of the first American lawyers to perceive that mere codification of the law did not necessarily produce certainty and lack of discord in the law of commercial transactions. Indeed, in the same article Eaton reveals that of the 1,091 cases that had arisen under the Negotiable Instruments Law, only 704 cited the Act and in the other 387 "the Negotiable Instruments Law [was] ignored by the courts in the decisions, and (so far as the reports show) by the counsel in these cases . . . ."2 Unlike Bentham, ${ }^{3}$ Carter, ${ }^{4}$ and Field," each of whom

* Professor of Law, The University of Michigan. B.A. 1956, Amherst College; J.D. 1962, The University of Michigan.-Ed.

$\dagger$ My thanks go to the fleas, Mark E. Klein (class of 1978) and Peter D. Winkler (class of 1977), for all manner of help in preparing this article. I am also indebted to James G. Cook (class of 1978) for doing the chi square tests and Bart T. Thomas (class of 1979) for Lexis assistance.

1. Eaton, On Uniformity in Judicial Decisions of Cases Arising Under the Uniform Negotiable Instruments Act, 12 MICH. L. REv. 89, 91 (1913).

2. Id. at 94 .

3. Jeremy Bentham was an unremitting British proponent of codification who wrote throughout the early part of the nineteenth century. His advocacy of codification extended not only to the common law of England, but to that of the United States as well. See J. BENTHAM, 4 Works (1843).

4. James Carter, a New York lawyer, was a leading opponent of codification in New York state. See J. Carter, Provinces of the Written and the UNWritTen LaW (1889); J. Carter, The Proposed Codification of OUR Common Law (1884).

5. David Dudley Field, also a New York lawyer and a contemporary of Carter, supra note 4, was the author of the "Field Code." Although it was enacted elsewhere, that code was never adopted by his home state. For an example of Field's

1262 
knew the truth about codification as only a true believer can know it, Eaton was willing to test his hypothesis against the actual case experience of the Negotiable Instruments Law.

His example has stimulated me to ask how one might measure both the gross and qualitative impact of the recodification of the sales law under article 2 of the Uniform Commercial Code (Code). The only source of empirical information about article 2's operation, at least for the lazy researcher, is the cases. Of course one who looks for the impact of the Code in the reported cases is engaging in almost precisely the same activity that has recently become fashionable in archeological and sociological circles, namely to study a society through its excreta, human or otherwise. Reported cases interpreting the Code are no more than the excreta, for they are disputes that the Code could not adequately resolve. They are important for what they tell us about the Code, where it works well and where it works badly, but in extrapolating from them one encounters the same risk that the archeologist faces when attempting to construct a model of an ancient society from the results of a single digging. Just as those results may represent a unique group in the society being studied, the reported cases may represent a unique and unrepresentative subsample of the Code's operation.

The reported cases may be unrepresentative for many reasons. To begin with, they doubtlessly involve greater financial stakes than the typical unreported case. ${ }^{\circ}$ In addition, probably they are mostly the kinds of cases, such as personal injury or warranty cases, where there is no continuing relationship between the disputants. Their composition is also likely to be influenced by the development of non-Code law in the state (such as strict tort liability) and perhaps even by the relative litigiousness of the residents in the various states.

Conceding the fallibility of our method of assessing the Code's impact, what do the cases show and how are they to be analyzed? First, of course, it is necessary to determine which Code sections have caused litigation and to organize the cases in some systematic way. To do that two research assistants and I skimmed every re-

side of the debate with Carter, see D. D. Fierd, Codification of Our Common Law: A Short Reply to a Long Essay, in 2 SPEECHES, ARguments, aNd Miscellaneous PAPers of David Dudley Field 494 (A.P. Sprague ed. 1884).

6. Common sense dictates that parties cannot afford to litigate every nickel and dime dispute. However, equally powerful forces may impede trial of the largest suits. Parties to commercial litigation involving substantial sums may choose to settle rather than litigate, either because they fear the consequences to their shareholders and others of an enormous and public loss, or because they are naturally conservative and do not wish to gamble for such large sums. 
ported article 2 case in New York, California, and Ohio for 1973, 1974, and 1975. We selected these three states because they are populous and important commercial states, because each is on the Lexis system, ${ }^{7}$ and because the Uniform Sales Act (Sales Act) preceded the Code in each. Using the Lexis system, we attempted to identify all article 2 cases in each of the three states during our selected three-year period. ${ }^{8}$ We then examined and identified each

7. Lexis is a legal research computer system operated by the Mead Corporation. The system contains the entire text of all the reported opinions from New York, Ohio, and California for the periods involved in this study.

8. The cases examined in our study were obtained from the Lexis system through a series of search requests. The search requests had to be formulated to coincide with the method by which each state cited the statutes (Uniform Commercial Code or Uniform Sales Act) and to limit the cases obtained to the specific time period desired (1/1/73 through $12 / 31 / 75$ for the Code and $1 / 1 / 59$ through $12 / 31 / 61$ or $1 / 1 / 62$ through 12/31/64 for the Sales Act). For example, article 2 of the Code is cited in Ohio as Revised Code (R.C.) 1302.01 et seq. Our initial Ohio search request was "(ucc or rc 1302!) and date $(>12 / 31 / 72$ and $<1 / 1 / 76)$." In Lexis the exclamation point tells the computer to search for all words in which the root "rc 1302" appears. Thus our search request obtained all the cases in which R.C. 1302.23 appeared, for example, as well as R.C. 1302.04 and 1302.98, as long as these cases were decided within the three-year period designated.

In formulating our search requests, our goals were to ensure that we obtained every case in which the Code or Sales Act was cited during the designated time periods in these jurisdictions, and to limit as much as possible the number of irrelevant and unrelated cases obtained. Since the first objective was the more important of the two, we continually reformulated our requests as we learned that one formulation or another failed to obtain certain cases. For example, we originally used the following search request to obtain cases that cited the Code in New York: "ucc or commercial code $w / 4 \S 2$ ! and date $(>12 / 31 / 72$ and $<1 / 1 / 76)$." The connective " $w / 4$ " instructs the computer to find all cases in which the first portion of the request appears within four words of the second portion of the request. Thus our request obtained any case in which "UCC" or "Commercial Code" appeared within four words of a statute cite beginning with the number two. We found, however, that there were cases in which there was no mention of UCC or the Commercial Code within four words of the citation. To retrieve those cases, we simply asked for all the cases from the appropriate years in which "UCC" or "Commercial Code" appeared. By skimming the Lexis readout for the cases so obtained, we eliminated those that did not cite article 2.

Certain peculiarities of the Lexis system necessitated the elimination of other search requests. In our search for California Code cases, we originally used the request: "ucc or com! code w/10 $22^{* *}$ or $23^{* *}$ or $24^{* *}$ or $25^{* *}$ or $26^{* *}$ or $27^{* *}$." The asterisks designate the last two digits of each statute number. The connector " $w / 10$ " was intended to eliminate cases in which the numbers appeared in an unrelated context such as $\$ 2,310$ or 2470 barrels of oil. The use of the double asterisks, however, resulted in too lengthy a search time. In one case we waited one and onehalf hours without an answer to the request quoted above. As a result, our final search request for California Code cases was essentially the same as that for the New York cases.

The previous discussion is only illustrative of the process we used. We utilized similar pigeon-brained trial and error methods elsewhere. The final search requests for both the Code and Sales Act cases were as follows:

California

- (ucc or com! code) and date $(>12 / 31 / 72$ and $<1 / 1 / 76)$

- (sales act) or (civ! code w/4 $\left(172^{*}\right.$ or $173^{*}$ or $174^{*}$ or $175^{*}$ or $176^{*}$ or 
reference to an article 2 section in each of those cases. Finally, we separately read each article 2 case decided in 1975 in each of the three states ${ }^{2}$ and filled out a questionnaire on each case in an attempt

$177^{*}$ or $178 *$ or $179 *$ or 1800$\left.)\right)$ and date $(>12 / 31 / 61$ and $<1 / 1 / 65)$

New York

- (ucc or com! code) and date $(>12 / 31 / 72$ and $<1 / 1 / 76)$

- (sales act) or (pers! prop! w/4 $\left(8^{*}\right.$ or $9^{*}$ or $10^{*}$ but not 10 or $11^{*}$ but not 11 or $12 *$ but not 12 or $13 *$ but not 13 or $14 *$ but not 14 or $15 *$ but not 15 )) Ohio

-1302 ! and date $(>12 / 31 / 72$ and $<1 / 1 / 76)$

-(sales act) or 1315 ! and date $(>12 / 31 / 58$ and $<1 / 1 / 62)$

9. By the process described in note 8 supra we found the following 42 cases decided under article 2 in California, New York, and in Ohio in 1975: Hauter v. Zogarts, 14 Cal. 3d 104, 534 P.2d 377, 120 Cal. Rptr. 681 (1975); Voth v. Wasco Pub. Util. Dist., 54 Cal. App. 3d 201, 126 Cal. Rptr. 533 (1975), vacated, 56 Cal. App. 3d 353, 128 Cal. Rptr. 608 (1976); Becker v. Volkswagen of America, 52 Cal. App. 3d 794, 125 Cal. Rptr. 326 (1975); Varco-Pruden, Inc. v. Hampshire Constr. Co., 50 Cal. App. 3d 654, 123 Cal. Rptr. 606 (1975); Gantry Constr. Co. v. American Pipe \& Constr. Co., 49 Cal. App. 3d 186, 122 Cal. Rptr. 834 (1975); People v. Ernst, 48 Cal. App. 3d 785, 121 Cal. Rptr. 857 (1975); Black v. Sullivan, 48 Cal. App. 3d 557, 122 Cal. Rptr. 119 (1975); Dorman v. International Harvester Co., 46 Cal. App. 3d 11, 120 Cal. Rptr. 516 (1975); Berman v. Dean Witter \& Co., 44 Cal. App. 3d 999, 119 Cal. Rptr. 130 (1975); Feld v. Henry S. Levy \& Sons, 37 N.Y.2d 466, 335 N.E.2d 320, 373 N.Y.S.2d 102 (1975); Victorson v. Bock Laundry Mach. Co., 37 N.Y.2d 395, 335 N.E.2d 275, 373 N.Y.S.2d 39 (1975); Schleimer v. Googe, 50 App. Div. 2d 944, 377 N.Y.S.2d 591 (1975); Owens v. Patent Scaffolding Co., 50 App. Div. 2d 866, 376 N.Y.S.2d 948 (1975); Owens v. Palm Tree Nursing Home, Inc., 50 App. Div. 2d 865, 376 N.Y.S.2d 946 (1975); Lincoln First Natl. Bank v. Grabowski, 50 App. Div. 2d 1074, 376 N.Y.S.2d 342 (1975); A.M. Knitwear Corp. v. All America Export-Import Corp., 50 App. Div. 2d 558, 375 N.Y.S.2d 23 (1975), affd., 41 N.Y.2d 14, 359 N.E.2d 342, 390 N.Y.S.2d 832 (1976); Decrosta v. Reynolds Constr. \& Supply Corp., 49 App. Div. 2d 476, 375 N.Y.S.2d 655 (1975); Infante v. Montgomery Ward \& Co., 49 App. Div. 2d 72, 371 N.Y.S.2d 500 (1975); Bankers Trust Co. v, Walker, 49 App. Div. 2d 670, 371 N.Y.S.2d 198 (1975); Gemini Typographers, Inc. v. Mergenthaler Linotype Co., 48 App. Div. 2d 637, 368 N.Y.S.2d 210 (1975); Rosen v. Hummel, 47 App. Div. 2d 782, 365 N.Y.S.2d 79 (1975); Lenkay Sani Prods. Corp. v. Benitez, 47 App. Div. 2d 524, 362 N.Y.S.2d 572 (1975); S. Kornblum Metals Co. v. Intsel Corp., 47 App. Div. 2d 523, 362 N.Y.S.2d 568 (1975), affd., 38 N.Y.2d 376, 342 N.E.2d 591, 379 N.Y.S.2d 826 (1976); American Trading Co. v. Fish, 87 Misc. 2d 193, 383 N.Y.S.2d 943 (Sup. Ct. 1975); C.M.I. Clothesmakers, Inc. v. A.S.K. Knits, Inc., 85 Misc. 2d 462, 380 N.Y.S.2d 447 (Sup. Ct. 1975); Estate of Rothko, 84 Misc. 2d 830, 379 N.Y.S.2d 923 (Sur. Ct. 1975); Johnny Dell, Inc. v. New York State Police, 84 Misc. 2d 360, 375 N.Y.S.2d 545 (Sup. Ct. 1975); United Equities Co. v. First Natl. City Bank, 84 Misc. 2d 441, 374 N.Y.S.2d 937 (Sup. Ct. 1975), revd., 52 App. Div. 2d 154, 383 N.Y.S.2d 6 (1976); Jennings v. Roosevelt Hosp., 83 Misc. 2d 1, 372 N.Y.S.2d 277 (Sup. Ct. 1975); Brooklyn Union Gas Co. v. Jimeniz, 82 Misc. 2d 948, 371 N.Y.S.2d 289 (Civ. Ct. N.Y. 1975); Sears, Roebuck \& Co. v. Enco Assocs., 83 Misc. 2d 552, 370 N.Y.S.2d 338 (Sup. Ct. 1975), affd., 54 App. Div. 2d 13, 385 N.Y.S.2d 613 (1976); Steinik v. Doctors Hosp., 82 Misc. 2d 97, 368 N.Y.S.2d 767 (Sup, Ct. 1975); Robert Mfg. Co. v. South Bay Corp., 82 Misc. 2d 250, 368 N.Y.S.2d 413 (Sup. Ct. 1975); Joseph P. Suchy, Inc. v. Stuerzel, 82 Misc. 2d 40, 370 N.Y.S.2d 316 (App. Term 1975); In re Estate of Young, 81 Misc. 2d 920, 367 N.Y.S.2d 717 (Sup. Ct. 1975); Weidman v. Tomaselli, 81 Misc. 2d 328, 365 N.Y.S.2d 681 (Sup. Ct.), affd. mem., 84 Misc. 2d 782, 386 N.Y.S.2d 276 (App. Term 1975); Curtis v. Fordham Chrysler Plymouth, Inc., 81 Misc. 2d 566, 364 N.Y.S.2d 767 (Sup. Ct. 1975); Henry Heide, Inc. v. Atlan- 
to identify certain factors discussed below. ${ }^{10}$ My intent was to have three reasonably well-informed and intelligent persons make independent judgments about each case. ${ }^{11}$

tic Mut. Ins. Co., 80 Misc. 2d 485, 363 N.Y.S.2d 515 (Sup. Ct. 1975); Cincinnati Bd. of Realtors v. Cincinnati, 47 Ohio App. 2d 267, 353 N.E.2d 898 (1975), affd. sub. nom. Wilson v. City of Cincinnati, 46 Ohio St. 2d 138, 346 N.E.2d 666 (1976); Eckstein v. Cummins, 46 Ohio App. 2d 192, 347 N.E.2d 549 (1975); Centennial Ins. Co. v. Tanny Intl., 46 Ohio App. 2d 137, 346 N.E.2d 330 (1975); Brown v. Christopher Inn Co., 45 Ohio App. 2d 279, 344 N.E.2d 140 (1975).

For our purposes, the "reported" cases include only those that are published in bound form in a regular reporting system. Thus we did not include cases that are reported only in the New York Law Journal or that may be reported in a similar fashion in California or Ohio.

The Code played such a tangential role in one of the cases (Cincinnati Bd. of Realtors v. Cincinnati, 47 Ohio App. 2d 267, 353 N.E.2d 898 (1975), affd. sub. nom Wilson v. City of Cincinnati, 46 Ohio St. 2d 138, 346 N.E.2d 666 (1976)) that we did not complete the questionnaire on that case.

10. The following is an edited version of the questionnaire used in analyzing the cases:

Cite

1. Sections:

Reviewer

2. Does either party advance a claim the success of which turns on a Uniform Sales Act/Uniform Commercial Code provision?

Yes

No (the section is tangential)

3. Does the court refer to the comments? If so, do they appear to affect the outcome? How?

4. Does either party seek the application of the Uniform Sales Act/Uniform Commercial Code by analogy, i.e., beyond its official scope?

- Yes

No

(a) If yes, to what area?

(b) Sensible analogy? Why?

5. Is the interpretation of the Uniform Commercial Code/Uniform Sales Act correct? (Correct $=$ in agreement with White and Summers' Handbook of Law Under the Uniform Commercial Code if it takes a position, otherwise in agreement with the apparent position of the drafters and the legislature)

- Correct

Incorrect

Unsure Why?

6. Is it a just result? (Would a layperson knowing the facts as stated in the opinion call it fair?)

7. Would it have been answered differently by prior law?

Y.Yes

-No

8. Is there any problem presented by the case that the Uniform Commercial Code/Uniform Sales Act drafters specially anticipated? If yes, in what way?

9. Is the interpretation of the Uniform Commercial Code/Uniform Sales Act provision consistent or inconsistent with the interpretations in other states?

- Consistent or reviewer unsure

-Inconsistent (reviewer knows of at least one that is different)

10. Is the application of the Uniform Commercial Code/Uniform Sales Act provision guidesome (guidesome $=$ court's analysis not incomplete, erroneous, or dependent upon unarticulated variables, e.g., a widow or consumer as plaintiff an influencing factor)

11. Dollar amount at stake:

12. General comments:

11. In perhaps ten per cent of the total decisions the three of us did not agree. A discussion at the conclusion of all our reviewing produced unanimity on all but 
Since article 2 was intended to replace and improve upon the Sales Act, we chose as a control a three-year set of Sales Act cases from the same three states and ran the same tests. ${ }^{12}$ By comparing the results we should be able to make a few observations about the Code's relative impact on commercial behavior.

\section{The Cases in Gross}

Before moving to the heart of our study and concluding that its findings are intuitively obvious, the reader should test his intuition by answering the following questions:

(1) How many article 2 cases are reported in the three states during the three-year span?

(2) Which article 2 sections are most frequently cited in the reported cases?

(3) Are there more or fewer cases under the Code than under the Sales Act?

one to two per cent of these decisions. In the cases where there was no unanimity we have reported the judgment of the majority.

12. We chose a later date for California than for New York and Ohio because the California cases for the 1959-61 period were not on the Lexis system, and there was no three-year segment when all three states were on the Lexis system and were governed by the Sales Act. Conceivably California cases for the years 1962-64 were different in some systematic way from the 1959-61 California cases because of differing economic conditions, change in the judiciary, or for other reasons. However, we know of no such differences, and there was nothing in the reported cases to support that idea.

As was done for the UCC cases, the cases from the last year of each three-year period (1964 for California and 1961 for New York and Ohio) were selected for the questionnaire analysis. The search procedure, see note 8 supra, modified for the Sales Act, retrieved 17 cases decided in the designated period. Vandermark v. Ford Motor Co., 61 Cal. 2d 256, 391 P.2d 168, 37 Cal. Rptr. 896 (1964); Sunset-Sternau Food Co. v. Bonzi, 60 Cal. 2d 834, 391 P.2d 168, 36 Cal. Rptr. 741 (1964); Alvarez v. Felker Mfg. Co., 230 Cal. App. 2d 987, 41 Cal. Rptr. 514 (1964); Mosekian v. Davis Canning Co., 229 Cal. App. 2d 118, 40 Cal. Rptr. 157 (1964); Walnut Creek Pipe Distrib., Inc. v. Gates Rubber Co., 228 Cal. App. 2d 810, 39 Cal. Rptr. 767 (1964); Santa Clara Sand \& Gravel Co. v. State Bd. of Equalization, 225 Cal. App. 2d 676, 37 Cal. Rptr. 506 (1964); Mack v. Hugh W. Comstock Assocs., 225 Cal. App. 2d 583, 37 Cal. Rptr. 466 (1964); Green v. Watson, 224 Cal. App. 2d 184, 36 Cal. Rptr. 362 (1964); Canadian Indem. Co. v. Motors Ins. Corp., 224 Cal. App. 2d 8, 36 Cal. Rptr. 159 (1964); Greenberg v. Lorenz, 9 N.Y.2d 195, 173 N.E.2d 773, 213 N.Y.S.2d 39 (1961); Albany Discount Corp. v. State of New York Natl. Bank, 15 App. Div. 2d 623, 222 N.Y.S.2d 518 (1961); Bidwell v. Long, 14 App. Div. 168, 218 N.Y.S.2d 108 (1961); Doherty v. Aaron Mach. Co., 33 Misc. 2d 459, 214 N.Y.S.2d 536 (Sup. Ct. 1961), modified, 18 App. Div. 2d 915, 238 N.Y.S.2d 179 (1963); Tracton v. A \& O Novelties Co., 32 Misc. 2d 991, 223 N.Y.S.2d 565 (Sup. Ct. 1961); Sheftman v. Balfour Housing Corp., 30 Misc. 2d 924, 219 N.Y.S.2d 461 (Sup. Ct. 1961); Sanchez-Lopez v. Fedco Food Corp., 27 Misc. 2d 131, 211 N.Y.S.2d 953 (New York City Ct. 1961); Ballinger \& Co. v. Grime, 16 Ohio Op. 2d 258 (Toledo Mun. Ct. 1961). 
(4) What are the significant differences between the case distributions under the Code and under the Sales Act?

(5) What are the significant differences between the case distributions of the three states?

\section{A. Distribution of the Cases by State}

Table 1 shows the distribution of Sales Act and Code cases among the three states for the years in question. For several reasons, New York has far more reported opinions than the other two states. The most significant reason is that New York trial courts publish their opinions, while those in California and Ohio usually do not. For example, fifteen of the twenty-nine 1975 New York cases are trial court opinions. ${ }^{13}$ Our search likely did not even turn up all of the pertinent cases recorded in the Lexis system. ${ }^{14}$ As a general proposition, we examined every case recorded in Lexis that contained the words "Sales Act," "Uniform Commercial Code," "UCC," or "Commercial Code." In some cases we used additional or slightly different requests. ${ }^{15}$ It is possible that there are some Code cases that did not contain our request words, but a manual comparison of the 1975 cases suggests that the number of such cases is very small. ${ }^{16}$

TABLE 1

Sales Act and Code Cases by State and Year

\begin{tabular}{cccc}
\hline & New York & Ohio & California \\
\hline USA & 32 & 11 & 32 \\
Cases & $(1959-61)$ & $(1959-61)$ & $(1962-64)$ \\
\hline UCC & 77 & 13 & 19 \\
Cases & $(1973-75)$ & $(1973-75)$ & $(1973-75)$ \\
\hline USA & 7 & 1 & 9 \\
Cases & $(1961)$ & $(1961)$ & $(1964)$ \\
\hline UCC & 29 & 4 & 9 \\
Cases & $(1975)$ & $(1975)$ & $(1975)$ \\
\hline
\end{tabular}

13. See cases cited in note 9 supra. However, these cases are not exhaustive of even the reported trial court opinions, since the Lexis system does not include cases that are reported only in the New York Law Journal. An examination of the UCC Reporting Service for 1975 revealed between 15 and 20 additional trial court decisions dealing with article 2, none of which are included in our sample, that were reported only in the New York Law Journal.

14. Since we did not search cases in the federal courts, federal cases arising in the three states are not included in the sample.

15. See note 8 supra.

16. To verify the completeness of our Lexis sample we checked three sources: The index in the UCC Reporting Service, the Shepard's statutory citator for each 


\section{B. Frequency of Citation to Article 2 Sections}

Table 2 shows the number of times each section of article 2 was cited in our three-year period; it contains only sections cited by at least one court. If a section was cited more than once in a case, it was recorded only once. Thus, for example, the numeral "2" under California next to section 2-201 means that section was cited in two cases during the three-year span. Of course the total number of cases cannot be determined from Table 2 because many cases contained citations to several sections. A significant but most unsurprising datum found on the chart is the fact that the warranty and warranty disclaimer sections were heavily cited. References to sec-

TABLE 2

uCC Sections Cited by State

\begin{tabular}{|c|c|c|c|c|c|c|c|}
\hline Section & $\begin{array}{c}\text { California } \\
\text { (1962- } \\
64)\end{array}$ & $\begin{array}{l}\text { New York } \\
\text { (1959- } \\
61)\end{array}$ & $\begin{array}{c}\text { Ohio } \\
\text { (1959- } \\
61)\end{array}$ & Section & $\begin{array}{c}\text { California } \\
\text { (1962- } \\
64)\end{array}$ & $\begin{array}{c}\text { New York } \\
\text { (1959- } \\
61)\end{array}$ & $\begin{array}{c}\text { Ohio } \\
\text { (1959- } \\
61)\end{array}$ \\
\hline $\begin{array}{l}2-101 \\
2-102 \\
2-103(1) \\
2-104(1) \\
2-105(1) \\
2-105(2) \\
2-105(3) \\
2-105(4) \\
2-106(1) \\
2-107 \\
2-201 \\
2-202 \\
2-204 \\
2-207 \\
2-208 \\
2-209 \\
2-210 \\
2-302 \\
2-306 \\
2-310 \\
2-311 \\
2-312 \\
2-313 \\
2-314 \\
2-315 \\
2-316 \\
2-318 \\
2-401 \\
2-403\end{array}$ & $\begin{array}{l}1 \\
1 \\
0 \\
0 \\
3 \\
0 \\
0 \\
0 \\
1 \\
0 \\
2 \\
0 \\
0 \\
0 \\
0 \\
2 \\
1 \\
1 \\
0 \\
0 \\
0 \\
0 \\
4 \\
4 \\
5 \\
2 \\
1 \\
1 \\
0\end{array}$ & $\begin{array}{r}0 \\
3 \\
0 \\
1 \\
1 \\
0 \\
0 \\
0 \\
1 \\
1 \\
3 \\
2 \\
0 \\
2 \\
1 \\
0 \\
0 \\
14 \\
2 \\
1 \\
1 \\
1 \\
5 \\
8 \\
5 \\
10 \\
3 \\
4 \\
1\end{array}$ & $\begin{array}{l}0 \\
1 \\
1 \\
2 \\
1 \\
1 \\
1 \\
1 \\
0 \\
0 \\
1 \\
1 \\
1 \\
2 \\
1 \\
0 \\
0 \\
3 \\
1 \\
0 \\
0 \\
0 \\
4 \\
3 \\
2 \\
3 \\
0 \\
1 \\
0\end{array}$ & $\begin{array}{l}2-501 \\
2-503 \\
2-506 \\
2-507 \\
2-509 \\
2-511 \\
2-601 \\
2-602 \\
2-606 \\
2-607 \\
2-608 \\
2-609 \\
2-610 \\
2-612 \\
2-614 \\
2-615 \\
2-708 \\
2-709 \\
2-710 \\
2-711 \\
2-712 \\
2-713 \\
2-714 \\
2-715 \\
2-716 \\
2-718 \\
2-719 \\
2-721 \\
2-725\end{array}$ & $\begin{array}{l}0 \\
0 \\
0 \\
1 \\
1 \\
0 \\
0 \\
0 \\
0 \\
1 \\
1 \\
0 \\
0 \\
1 \\
0 \\
0 \\
0 \\
2 \\
0 \\
0 \\
0 \\
0 \\
1 \\
2 \\
0 \\
3 \\
2 \\
0 \\
2\end{array}$ & $\begin{array}{r}1 \\
2 \\
0 \\
1 \\
3 \\
1 \\
1 \\
2 \\
2 \\
3 \\
0 \\
2 \\
1 \\
1 \\
1 \\
2 \\
1 \\
0 \\
1 \\
3 \\
1 \\
2 \\
2 \\
5 \\
1 \\
1 \\
2 \\
0 \\
18\end{array}$ & $\begin{array}{l}0 \\
0 \\
1 \\
0 \\
0 \\
0 \\
0 \\
0 \\
0 \\
1 \\
0 \\
0 \\
0 \\
0 \\
0 \\
0 \\
0 \\
0 \\
0 \\
0 \\
0 \\
0 \\
2 \\
1 \\
0 \\
0 \\
2 \\
1 \\
2\end{array}$ \\
\hline
\end{tabular}

state, and each California Reporter for the year 1975. That examination turned up three additional cases in California but no additional cases in New York or Ohio. We had probably scanned two of the California cases on the Lexis computer but had rejected them as article 9 cases, overlooking the references to article 2, for the predominant Code reference in those two cases was to article 9. Nowhere in the remaining California case, which involved a warranty on the sale of goods, did the court cite the Code. See Camrosa County Water Dist. v. S.W. Welding \& Mfg. Co., 17 UCC REP. SERv. 780 (1975). 
tions 2-313 through 2-316 comprise a substantial plurality of all the citations from each of the three states studied. ${ }^{17}$

Other results revealed by the chart were less predictable. How many would intuitively identify section 2-725 (the statute of limitations) as the most frequently cited article 2 section? Its citation is but a proxy for the continuing confusion in New York and in some other states between extra-Code tort law and intra-Code warranty law. Because different statutes of limitation apply in New York depending on whether one is within the Code or without, it is often in the interest of the plaintiff or the defendant to argue for or against the application of section 2-725. Those citations together with the frequent references in cases to the warranty and disclaimer sections probably reveal the most significant failure of the drafters of article 2. They did not adequately anticipate the enormous blossoming of strict tort and other forms of extra-Code strict liability and did not foresee the considerable potential for confusion between the Code provisions and such strict tort doctrines. For reasons that are not absolutely clear, the parties in California cases have not fought over the application of section $2-725$ in the same way as the New Yorkers. ${ }^{18}$

Not surprisingly, the next most frequently cited section in New York is section 2-302 on unconscionability. Much of the case de$2-316$.

17. Fifty-five of the 219 citations were references to $\$ \S 2-313,2-314,2-315$, or

18. In Becker v. Volkswagen of America, 52 Cal. App. 3d 794, 125 Cal. Rptr. 326 (1975), the court held that actions by plaintiffs who had suffered personal injuries against a manufacturer or seller were governed by the limitation period for personal injuries. CaL. Crv. Proc. CoDe \$ 340(3) (West Supp. 1977). That period is one year from the date of injury. The plaintiff had argued that he should be permitted to bring suit any time within four years of the sale under CaL. U. CoM. CoDE $\S 2725$ (West Supp. 1977). In rejecting his argument, the court pointed out that California has long recognized personal injury actions based on warranty as essentially tort actions and thus distinct from warranty liability under the Uniform Commercial Code. The court cited Greenman v. Yuba Power Prods., Inc., 59 Cal. 2d 57, 377 P.2d 897, 27 Cal. Rptr. 697 (1963), and Seely v. White Motor Co., 63 Cal. 2d 9, 403 P.2d 145, 45 Cal. Rptr. 17 (1965).

Since the limitation period under $\$ 2725$ is different from that under a typical tort statute and starts running at a different time, one of these statutes can be more favorable to the plaintiff than the other in different fact situations. Ironically, both Greenman and Seely were cases in which the California Supreme Court was endeavoring to expand the plaintiff's opportunity to recover and to strike down the restrictions that would have impeded his way in a warranty action. A cynical legal realist looking at the work of Roger and his boys might conclude that Justice Traynor was really following the principle that "the plaintiff shall win at all costs." If that is the governing principle in Greenman and the following cases, then the court in Becker has misread Justice Roger Traynor.

This early exclusion of personal injury actions unquestionably has helped minimize the confusion surrounding $\$ 2725$. However, it is not a complete explanation for the lack of litigation in California. 
velopment of that section has occurred in that state, and several of the most prominent decisions have come from New York. ${ }^{19}$ The chart shows one citation of section 2-302 in a California case, ${ }^{20}$ but that citation is merely a reference to the section in the Uniform Commercial Code, for California has not enacted section 2-302. One wonders under what rubric the New York unconscionability cases travel in California.

The complete absence of citation to certain sections is perhaps the most interesting information contained in Table 2 . There are 219 separate entries on the chart, an average of 2.1 entries for each Code section. If one excluded sections that were not cited at all, as done in Table 2, the median and average number of the citations would be two and four, respectively. Worthy of note among the sections not cited in any of the cases in any of the states are sections 2-205 (firm offers), 2-319 and 2-320 (f.o.b., f.a.s., and c. \& f. terms), 2-508 (cure), and 2-510 (risk of loss). Sections 2-508 and 2-205 were thought to be important and innovative Code sections, and, at least in the scholarly literature, section 2-508 has produced a good deal of discussion concerning its ambiguity. ${ }^{21}$ Among the sections cited only once were sections 2-204 (formation of contracts), 2-403 (good faith purchase), 2-601 (rejection rights), and 2-608 (revocation). What teacher of Sales would have predicted these results? ${ }^{22}$

If one excludes buyer's warranty remedies, the citations to part 7 sections of article 2 were fewer than I would have predicted. The rejection and revocation area collected only six citations. All of seller's damages from sections 2-703 through 2-710 were cited only four times, and two of those were in actions for the price. Excluding citation of sections 2-714 and 2-715 on the ground that most were warranty cases, buyer's remedies produced only six citations.

19. See, e.g., Jefferson Credit Corp. v. Marcano, 60 Misc. 2d 138, 302 N.Y.S.2d 390 (Civ. Ct. N.Y. 1969); Jones v. Star Credit Corp., 59 Misc. 2d 189, 298 N.Y.S.2d 264 (Sup. Ct. 1969); Central Budget Corp. v. Sanchez, 53 Misc. 2d 620, 279 N.Y.S. 2d 391 (Civ. Ct. N.Y. 1967); Frostifresh Corp. v. Reynoso, 52 Misc. 2d 26, 274 N.Y.S.2d 757 (Dist. Ct. 1966), revd. on issue of relief, 54 Misc. $2 \mathrm{~d} 119,281$ N.Y.S. 2d 964 (App. Term 1967); State ex rel. Lefkowitz v. ITM, Inc., 52 Misc. 2d 39, 275 N.Y.S.2d 303 (Sup. Ct. 1966).

20. See Dorman v. International Harvester Co., 46 Cal. App. 3d 11, 21, 120 Cal. Rptr. 516, 523 (1975).

21. See J. WhITE \& R. SUMmeRs, HaNDBOOK OF THE LAW UNDER THE UNIFORM COMMERCIAL CODE 266-70 (1972); Hawkland, Curing an Improper Tender of Title to Chattels: Past, Present and Commercial Code, 46 MInN. L. REv. 697 (1962); Peters, Remedies for Breach of Contracts Relating to the Sale of Goods Under the Uniform Commercial Code: A Roadmap for Article Two, 73 YALE L.J. 199, 20916 (1963).

22. In the interest of job security in these times of financial stringency perhaps I should have suppressed these findings, but love of truth prevailed. 
What should one conclude from these data? One explanation might be that the sections are so straightforward, clear, and well understood that they resolve potential disputes without need of litigation. Though that may be true of sections 2-319 and 2-320 on f.o.b., f.a.s. and c. \& f. terms, it could hardly be the case for sections 2-508 on cure, 2-608 on revocation of acceptance, or 2-403, a rather troublesome provision on good faith purchase. Thus the hypothesis may explain the lack of citation to some of the sections, but it is hardly adequate to explain the absence of citation to most of the sections. A second possible hypothesis is that the excreta did not adequately reflect the commercial disputes. Thus, one might argue that there were hundreds of unreported cases or thousands of unlitigated disputes that dealt with sections $2-403$ or $2-708 .{ }^{23}$ But if that were so, why were some not litigated, and others not appealed, while other disputes ended up in appellate courts? The absence of any persuasive answer to that question suggests that there were not hundreds of unreported cases.

The presence of many warranty cases in the sample is easier to to explain: many of these warranty cases are brought by an allegedly injured consumer-buyer against the seller, with whom he has no continuing relationship. Unlike the businessperson, the consumer-buyer pays no added litigation cost in the form of injured or severed business relationships. Presumably most cure, rejection, and revocation cases would arise between commercial buyers and sellers, parties desirous of preserving their relations with one another and therefore willing to forego a lawsuit and the possibility of immediate gain in order to sustain a long-term benefit.

In summary, the resounding message of these data is that, warranty litigation aside, appellate and presumably lower courts deal only infrequently and sporadically with article 2 of the Code. If the article is used as infrequently by planners and negotiators of nonlitigated disputes, the significance that the law school curriculum assigns to sales contracts, and perhaps to contracts in general, is unwarranted. ${ }^{24}$

23. It is now beyond dispute that there are many conflicts for each trial and many trials for each appeal. See J. Frank, CouRTS on TRIAL 33 (1949); Rosenberg \& Sovern, Delay and the Dynamics of Personal Injury Litigation, 59 CoLUM. L. REv. 1115 (1959). See generally Conard, The Economic Treatment of Automobile Injuries, 63 MICH. L. REv. 279, 285-86 (1964).

24. A look at the total number of appellate cases in the three sample states during the years in question provides some evidence of the relative infrequency of sales-contract litigation. It also serves as a means of comparing the significance of the Uniform Sales Act and the Uniform Commercial Code within each state. (Unfortun- 
TABLE 3

Citations to Comparable Sections of UCC \& Sales ACt (includes only sections cited)

\begin{tabular}{|c|c|c|c|c|c|}
\hline \multicolumn{3}{|c|}{ Uniform Commercial Code } & \multicolumn{3}{|c|}{ Uniform Sales Act } \\
\hline Section & $\begin{array}{c}\text { Number } \\
\text { of } \\
\text { Citations }\end{array}$ & $\begin{array}{c}\text { Percentage } \\
\text { of Total } \\
\text { UCC Citations } \\
\end{array}$ & Section & $\begin{array}{c}\text { Number } \\
\text { of } \\
\text { Citations }\end{array}$ & $\begin{array}{c}\text { Percentage } \\
\text { of Total } \\
\text { USA Citations }\end{array}$ \\
\hline $2-201$ & 6 & 2.7 & 4 & 8 & 7.5 \\
\hline $\begin{array}{l}2-204,2,205 \\
2-206,2-207\end{array}$ & 5 & 2.3 & 1,3 & 5 & 4.7 \\
\hline $2-301$ & 0 & 0 & 11,41 & 1 & 0.9 \\
\hline $2-304$ & 0 & 0 & $9(2), 9(3)$ & 2 & 1.9 \\
\hline $2-305$ & 0 & 0 & 9,10 & 2 & 1.9 \\
\hline $2-309(1)$ & 0 & 0 & $\begin{array}{l}43(2), 45(2), \\
47(1), 48 \\
\end{array}$ & 1 & 0.9 \\
\hline $2-310$ & 1 & 0.5 & $42,47(2)$ & 0 & 0 \\
\hline $\begin{array}{l}2-312,2-313 \\
2-314,2-315\end{array}$ & 42 & 19.2 & $\begin{array}{l}12,14,15(1), \\
15(2), 15(4), \\
15(5), 16\end{array}$ & 28 & 26.4 \\
\hline $2-316$ & 15 & 6.9 & 71 & 4 & 3.8 \\
\hline $2-401$ & 6 & 2.7 & $17,18,19,20$ & 11 & 10.4 \\
\hline $2-403$ & 1 & 0.5 & $\begin{array}{l}20(4), 23, \\
24,25\end{array}$ & 4 & 3.7 \\
\hline $2-504$ & 0 & 0 & 46 & 1 & 0.9 \\
\hline $2-507$ & 2 & 0.9 & $11,41,42$ & 1 & 0.9 \\
\hline 2.509 & 4 & 1.8 & $22,19,18$ & 11 & 10.4 \\
\hline $2-511$ & 1 & 0.5 & 42 & 0 & 0 \\
\hline $2-601$ & 1 & 0.5 & 11,44 & 1 & 0.9 \\
\hline $\begin{array}{l}2-602,2-606 \\
2-608\end{array}$ & 5 & 2.3 & $\begin{array}{l}48,50,69(1)(d \\
69(3), 69(4), \\
69(5)\end{array}$ & 1), & 15.1 \\
\hline $2-607$ & 5 & 2.3 & 41,49 & 6 & 5.7 \\
\hline $2-609$ & 2 & 0.9 & $\begin{array}{l}53,54(1)(\mathrm{b}), \\
55,63(2)\end{array}$ & 3 & 2.8 \\
\hline 2.610 & 1 & 0.5 & $63(2), 65$ & 2 & 1.9 \\
\hline $2-612$ & 2 & 0.9 & $45(2)$ & $\mathbf{0}$ & 0 \\
\hline $2-702(1)$ & 0 & $\mathbf{0}$ & $\begin{array}{l}53(1)(\mathrm{b}), \\
54(1)(\mathrm{c}), 57\end{array}$ & 1 & 1.9 \\
\hline $2-702(3)$ & 0 & 0 & $76(3)$ & 1 & 1.9 \\
\hline $2-704$ & 0 & 0 & $63(3), 64(4)$ & 4 & 3.8 \\
\hline $2-706$ & 0 & 0 & 60 & 2 & 1.9 \\
\hline $2-708$ & 1 & 0.5 & 64 & 2 & 1.9 \\
\hline $2-709$ & 2 & 0.9 & 63 & 2 & 1.9 \\
\hline $2-710$ & 1 & 0.5 & 64,70 & 4 & 3.8 \\
\hline $2-713$ & 2 & 0.9 & $67(3)$ & 1 & 0.9 \\
\hline $2-714,2-715$ & 13 & 6.0 & 69,70 & 15 & 14.2 \\
\hline $2-716$ & 1 & 0.5 & 68 & 1 & 0.9 \\
\hline $2-717$ & $\overline{0}$ & 0 & $69(1)(a)$ & 13 & 12.3 \\
\hline
\end{tabular}




\section{Case Distribution by UCC and USA Section}

Table 3 compares the citations to various sections of the Code with citations to analogous sections of the Sales Act. In assessing the statistics, the reader should appreciate that in many cases there is either no precise analogue in the Sales Act for the article 2 provision or the corresponding sections of the Sales Act are not coextensive with the provision of article 2. For example, section 69 of the Sales Act is not only the basic buyer's damage section but also includes a provision on rights and procedures concerning buyer's return of goods.

Despite these difficulties in comparison, one finds that several Code sections caused significantly less litigation than did the comparable Sales Act provisions. Section 2-201 (statute of frauds) produced six citations in our study, or 2.7 per cent of the total article 2 citations, whereas the eight citations for the comparable Sales Act provision represented 7.5 per cent of the total for that act. ${ }^{25}$ More dramatically, section 2-509 on risk of loss produced only four citations, less than 2.0 per cent of the total Code cites, but the comparable sections of the Sales Act produced 11 citations, 10.4 per cent of the total. Similar comparisons of section 69 of the Sales Act and sections 2-714 and 2-715, or 2-602, 2-606 and 2-608 of the Code

ately, the states differ in their methods of compiling information on appellate cases).

In California, the total number of filings in the supreme court and courts of appeal reported by fiscal year are as follows: 1961-62, 4,688; 1962-63, 5,138; 1963$64,5,744 ; 1964-65,7,141 ; 1972-73,12,325 ; 1973-74,13,318 ; 1974-75,14,017$. These figures include a small number of cases transferred from the courts of appeal to the supreme court; this may involve double counting. JUDICIAL CouncIL OF CALIfORNIA, ANNUAL REPORT OF THE ADMINISTRATIVE OFFICE OF THE CALIFORNia COURTS, Judicial Statistics For the Fiscal Year 1964-65 (1966); Judicial CounCil of California, Annual Report of the Administrative Office of the CaliFORNIA COURTS (1976).

In New York, the total number of appeals filed with the court of appeals and the appellate division of the supreme court reported by fiscal year are as follows: $1958-59,2,420 ; 1959-60,2,684 ; 1960-61,2,992 ; 1961-62,3,088 ; 1972-73,6,324 ; 1973-$ 74, 6,777; 1974-75, 8,030. REPORT OF THE ADMINISTRATIVE BOARD OF THE JUDICIAL CONFERENCE of tHe STATE of NEW York $(1960,1961,1962,1963,1974,1975$, 1976). The figures for 1973-74 and 1974-75 were received by telephone from the New York Office of Public Information.

In Ohio, the total number of filings each year in the supreme court and courts of appeal are as follows: $1959,2,328 ; 1960,2,345 ; 1961,2,500 ; 1973,6,048 ; 1974$, 6,$690 ; 1975,8,174$. FourteENTH ANNUAL REPORT OF THE Judicial CounCil of OHIO (1959); FIFTEENTH ANNUAL REPORT OF THE Judicial CoUnCIL OF OHIO (1960); Ohro CourTs Summary 1969 (data for 1961); OHo Courts Summary 1975 (data for 1973, 1974, 1975).

25. The difference between the distributions under the Sales Act and under article 2 are statistically significant. The chi-square test shows a .045 value. That is to say, the distributions of the cases under the two Acts that we have observed would occur by chance alone in no more than four and one-half per cent of the cases. 
are probably invalid for lack of coextensiveness, as discussed above, and doubtless the same is true of the apparent difference between the citations under section 2-401 of the Code and the citations under sections 17, 18, 19, and 20 of the Sales Act. Finally, the amount of article 2 litigation directed toward warranty makes up only 19 per cent of the total cites to the Code, whereas it comprises 26 per cent of the Sales Act total. ${ }^{20}$

From these comparative statistics it seems fair to conclude that the Code has not caused a radical change in the type of sales litigation that appears in the reported opinions. Perhaps the drafters of the Code can take credit for the reduction of litigation under section 2-201, a carefully constructed and comprehensive provision. From reported cases in the study and elsewhere it is clear that section 2-201 is in an area where there is considerable conflict; thus the small number of cases under the section is not the result of an absence of real disputes. ${ }^{27}$

The difference between cases under section 2-509 and those under sections 18, 19, and 22 perhaps represents the Code's most dramatic success. Those old enough to have read many Sales Act cases remember the intricate determinations of when "title passed" and consequently whether the seller or the buyer had the risk of loss for the cream that spoiled en route or the tires that were stolen. ${ }^{28}$ Here the drafters of the Code gave legal meaning to the symbols routinely used by businesspersons, ${ }^{29}$ and, by adopting a set of fairly clear if somewhat rigid rules, succeeded in eliminating litigation in a formerly troublesome area.

It is harder to credit the drafters with the reduction in litigation over the warranty provisions. Litigation in that area is so obviously influenced by non-Code developments in the common law of the various states that one must hesitate to single out the Code's modest

26. The chi-square test applied to this distribution shows a .09 value. Thus, if we accept the convention of statistical significance which says that differences are not treated as statistically significant unless they have a value lower than .05 , we should conclude that this difference is not statistically significant. To put it another way, the odds are about one in ten that chance alone could have generated this distribution.

27. See, e.g., Continental Grain Co. v. Martin, 536 F.2d 592 (5th Cir.), cert. denied, 97 S. Ct. 643 (1976); Continental Grain Co. v. Brown, - F. Supp. 19 UCC Rep. SERv. 52 (W.D. Wis. 1976); Farmers Elevator Co. v. Anderson, Mont. -, 552 P.2d 63 (1976).

28. See, e.g., Raylo Lumber Co. v. Oregon Pac. Lumber Co., 222 Ore. 257, 352 P.2d 749 (1960).

29. See UCC $\$ \$ 2-319$ (F.O.B. and F.A.S. terms), 2-320 (C.I.F. and C. \& F. terms), and 2-509 (risk of loss in the absence of breach). 
changes in the articulation of warranty liability as responsible for the reduction in the percentage of litigation from 26 to 19 per cent.

In conclusion, the data give little support to the notion that article 2's adoption has significantly changed the general distribution of Sales cases. There is some evidence that a few sections, such as 2-201 and 2-509, have produced significantly less litigation than their Sales Act analogues, but that is the most one can say.

\section{Some Specific Tests for Measuring the QUALITY OF THE CODE}

The foregoing discussion deals with article 2's appropriate place in the legal universe. It considers only whether the article is a large and prominent star or simply a small and relatively insignificant one. Of equal importance is the question of the article's legal quality. Presumably the Code was not enacted simply to change the law and thus provide lawyers and legislators with more work. Rather, the drafters hoped that the law would be improved and become clearer, more just, and more appropriately flexible. At the time of its proposal, few in academe did not believe that the Code was an improvement on the prior law. ${ }^{30}$ Since that time fewer still have challenged the proposition that the Code represented a large step forward in legal quality.

To evaluate that proposition, we did two things. First we skimmed a three-year segment of Sales Act and another three-year segment of UCC cases from New York, Ohio, and California. We did not read each of the cases but rather noted the Sales Act or article 2 citations in each of them. Secondly, each of us read each Sales Act case and each article 2 case in the three states for a oneyear period. From the data collected from the skimming of the three-year group and from the careful reading of the one-year group, we have attempted to make an objective evaluation of the differences in the cases under the two statutes and to measure any changes in quality between those two bodies of cases.

30. The most persistent and vocal academic opponent of the Code was Professor Beutel. See Beutel, The Proposed Uniform [?] Commercial Code Should Not Be Adopted, 61 YAIE L.J. 334 (1952); Beutel, The Proposed Uniform [?] Commercial Code Should Not Be Adopted in Ohio, 14 OHIo ST. L.J. 3 (1954). For other opinions of the Code at the time of its adoption, see Symposium: The Uniform Commercial Code-A Third Look?, 14 CASE W. RES. L. REV. 7 (1962); Symposium on the Uniform Commercial Code, 17 Rutgers L. REv. 1 (1962); Symposium: The Uniform Commercial Code, 48 Cornell L.Q. 1 (1962); Note, The Uniform Commercial Code: The Effect of Its Adoption in Tennessee, 22 TENN. L. REV. 776 (1953). 


\section{A. Justness}

An obvious measure of the quality of law is whether it produces just results. For our purposes a result was just if "a layperson knowing the facts as stated in the opinion would call it fair." Of the fortyone Code cases reviewed under this standard, we concluded that thirty-nine were just and one was unjust; ${ }^{31}$ we were unsure about the justness of one result. ${ }^{32}$ Applying the same test, we concluded that seventeen out of seventeen Uniform Sales Act cases produced just results.

On the basis of those statistics, the Code could hardly be said to have made an improvement over the Sales Act, though the numbers probably do not indicate a retrogression, either. ${ }^{38}$ In general we were perhaps too generous in labeling results just, but, as Jerome Frank might have maintained in a glib moment, "the courts always produce just results, and the statutes have little or no impact on them."34 Professor Frank probably would not have gone as far as that, but the legal realist's hypothesis merits consideration, for perhaps no commercial statute can be enacted that would have more than a marginal impact on the "justness" of outcomes in American courts. A second plausible explanation for the fact that almost all outcomes appeared to be just is the notorious judicial propensity to

31. Curtis v. Fordham Chrysler Plymouth, Inc., 81 Misc. 2d 566, 364 N.Y.S.2d 767 (Civ. Ct. 1975). Plaintiff buyer brought an action for damages and the return of the purchase price of his automobile against both the dealer and the manufacturer on theories of negligence and implied warranty of merchantability. The plaintiff claimed the car was "hard starting" and the motor would "cut out" even after a long series of repairs by the dealer. After about a year, plaintiff removed the license plates and returned the car to the dealer's lot, where it sat for two years pending trial. Finding for the defendant, the court rejected plaintiff's evidence of damages (cost of new batteries and towing charges) and held that the return did not constitute revocation because it was not accompanied by plaintiff's transfer stub or other title document.

32. Owens v. Patent Scaffolding Co., 50 App. Div. 2d 866, 376 N.Y.S.2d 948 (1975). In action for personal injuries arising out of a lease transaction, the court approved the use of Code implied warranty provisions ( $\$ \S 2-314$ and 2-315) but rejected the Code's statute of limitations ( $\$ 2-725)$. (Two reviewers found this to be incorrect and unguidesome and were unsure as to its justness. The third reasoned that since the warranty provisions were applied by analogy, there was no inconsistency in selective borrowing.)

Question six of the questionnaire, note 10 supra, asking whether results were just, was generally answered from the point of view of a thoughtless liberal. That is to say, the answers more closely approximated the position of a Ralph Nader than of a Milton Friedman.

33. The distribution has a .48 chi-square, indicating that this distribution would have occurred by chance alone about half the time.

34. The quoted language is not that of Jerome Frank. We are wickedly reconstructing history. 
include in opinions only those facts that support the result. ${ }^{35}$ In any event our data do not support the argument that article 2 made the law more just than it was under the Sales Act.

\section{B. Consistency, Certainty, Accuracy}

All law must strike a balance between flexibility on the one hand and certainty on the other. Depending upon the particular case, either attribute may better serve the ends of fairness. For the most part I would argue that certainty should be the goal of commercial law, at least in those cases where the parties are free to make their own law in the form of contracts. Seldom is society served by businesses litigating with one another over commercial deals. Different considerations apply when one party is a consumer and has neither the capacity nor the will to negotiate his own contract.

To ask whether the Code is certain is to ask whether the courts have interpreted the language as it was intended to be interpreted. An added element in the consistency and certainty formula is the question of interstate consistency in the interpretation of the various sections. To evaluate those factors we asked the following questions: (1) Is the case a correct interpretation of the Code or the Sales Act? ${ }^{36}$ (2) Is the case consistent with other cases in the same state or elsewhere? As with the examination of fairness we found no significant differences between the percentage of the Sales Act cases and the percentage of article 2 cases that were "correct." Table 4 summarizes our findings. ${ }^{37}$

35. See J. FranK, supra note 23 , at $23,165-85,222-24$.

36. In this context a Uniform Commercial Code case was "correct" if it agreed with J. WHITE \& R. Summers, supra note 21, or, when White and Summers did not take a position, if it agreed with the apparent position of the drafters and the legislature. (Our test may seem a bit inbred and-egotistical, but it had the virtue of ease of application.)

A Sales Act case was correct if it agreed with the apparent position of the drafters and the legislature. L. Vold, HANDBOOK OF THE LAW OF SAles (2d ed. 1959) was occasionally used as an authority. In general, judgments about the correctness of Sales Act cases were more tentative than those involving the Code.

37. We concluded that the courts reached incorrect results in three of the UCC cases. In Gantry Constr. Co. v. American Pipe \& Constr. Co., 49 Cal. App. 3d 186, 122 Cal. Rptr. 834 (1975), a slander action arising out of statements made by a creditor to plaintiff's bonding company, the court implied that $\$ 2-709$ authorizes acceleration in the absence of an acceleration clause when the buyer fails to pay. The court ignored $\$ \S 2-609,2-610$ and 2-612. The court in S. Kornblum Metals Co. v. Intsel Corp., 47 App. Div. 2d 523, 362 N.Y.S.2d 568 (1975), affd., 38 N.Y.2d 376, 342 N.E.2d 591, 379 N.Y.S.2d 826 (1976), mistakenly applied \$ 2201 (Statute of Frauds) in deciding whether a contract was formed and what its terms were on the basis of an oral agreement and a purchase order containing an arbitration clause. It ignored the relevant Code provision, $\$ 2-207$ (additional terms 
We also concluded that about the same percentage of cases produced results inconsistent with other decisions under the Sales Act as under article 2. That result has limited significance because it is largely a product of the warranty-tort conflict. We marked a case as inconsistent with other cases in almost every situation involving the statute of limitations. We did that because we knew that there

TABLE 4

CORRECTNESS OF USA AND UCC CASES

\begin{tabular}{ccc}
\hline Correct Decision & USA & UCC \\
\hline Yes & $13(76 \%)$ & $33(80.5 \%)$ \\
\hline No & $0(0 \%)$ & $3(7.3 \%)$ \\
\hline Unsure & $4(24 \%)$ & $5(12.2) \%$ \\
\hline
\end{tabular}

would be cases elsewhere, perhaps within the same state, applying the statute of limitations differently. ${ }^{38}$ Thus the data did not adequately measure the extent to which the Code has produced consistency across state lines. One would have to study a larger number of cases with greater care in order to arrive at a reliable conclusion about consistency. One can say only that our data do not support a conclusion that the enactment of the Code has increased consistency; they do not really challenge that conclusion, either.

It is disheartening that from even as small a sample as ours one cannot conclude that article 2's results are more "correct" and consistent than those under the Sales Act. Article 2 was built upon the experience of the Sales Act and presumably benefited from the errors made there. Moreover, it was carefully constructed and con-

in acceptance and confirmation). The third case, Owens v. Patent Scaffolding Co., 50 App. Div. 2d 866, 376 N.Y.S.2d 948 (1975), is discussed in note 32 supra.

We were unsure of the correctness of the results in five UCC cases. Becker v. Volkswagen of America, 52 Cal. App. 3d 794, 125 Cal. Rptr. 326 (1975), discussed in note 18 supra; Varco-Pruden, Inc. v. Hampshire Constr. Co., 50 Cal. App. 3d 654, 123 Cal. Rptr. 606 (1975) (Code risk of loss provision (\$ 2-509), without discussion of the scope provisions of article 2 , held inapplicable to losses due to fire at a construction site because the agreement did not constitute a sale within the contemplation of the Code); Infante v. Montgomery Ward \& Co., 49 App. Div. 2d 72, 371 N.Y.S.2d 500 (1975) (Code statute of limitations ( $\$ 2-725$ ) held not applicable to action in strict liability based on injuries resulting from pajamas which caught fire); Sears, Roebuck \& Co. v. Enco Assocs., 83 Misc. 2d 552, 370 N.Y.S.2d 338 (Sup. Ct. 1975), affd., 54 App. Div. 2d 13, 285 N.Y.S.2d 613 (1976) (contract underlying warranty action against architect for defective cement parking ramps held sale of service and thus outside article 2); Joseph P. Suchy, Inc. v. Stuerzel, 82 Misc. 2d 40, 370 N.Y.S.2d 316 (App. Term 1975) (funeral services involving furnishing of casket held sale of services outside article 2 ).

38. See note 18 supra. 
tains comments that have often assisted the courts. ${ }^{30}$ One would hope that the study of a large enough number of cases would lead to the conclusion that the Code produces a larger number of "correct" outcomes than did the Uniform Sales Act.

\section{C. "Guidesomeness"}

A corollary to the question of the correctness of the cases' interpretation of the drafter's intent is the question whether the cases are "guidesome." Even though a case might be classified as "correct" or "just," it might fail to guide the unsophisticated lawyer if the court inadequately analyzed the doctrine it relied upon or based its decision on an unarticulated premise. We labeled a case not guidesome if it appeared that the true determinants of the outcome were not articulated or if the court, while coming to an arguably correct conclusion, analyzed Code principles incorrectly or insufficiently and thus opened the way for subsequent misinterpretation. As Table 5 shows, we found no significant difference in guidesomeness between the Sales Act and the Code cases. ${ }^{40}$ Five of the cases ${ }^{41}$ were classified as not guidesome because of their garbled inter-

TABLE 5

"Gutdesomeness" of USA AND UCC CASES

\begin{tabular}{ccc}
\hline Guidesome & USA & UCC \\
\hline Yes & $13(76 \%)$ & $30(73.2 \%)$ \\
\hline No & $4(24 \%)$ & $11(26.8 \%)$ \\
\hline
\end{tabular}

39. The official comments were cited in $21 \%$ of the cases in our sample of 1975 Code cases. In over half of these cases, we found that the comments contributed to the interpretation of the Code provisions. See, e.g., Berman v. Dean Witter \& Co., 44 Cal. App. 3d 999, 119 Cal. Rptr. 130 (1975); Feld v. Henry S. Levy \& Sons, 37 N.Y.2d 466, 335 N.E.2d 320, 373 N.Y.S.2d 102 (1975); Henry Heide, Inc. v. Atlantic Mut. Ins. Co., 80 Misc. 2d 485, 363 N.Y.S.2d 515 (Sup. Ct. 1975).

40. The chi-square was .79 , and thus chance likely caused this difference.

41. See Varco-Pruden, Inc. v. Hampshire Constr. Co., 50 Cal. App. 3d 654, 123 Cal. Rptr. 606 (1975), discussed in note 37 supra; DeCrosta v. A. Reynolds Constr. \& Supply Corp., 49 App. Div. 2d 476, 375 N.Y.S.2d 655 (1975) (considerable confusion about the appropriate statute of limitations in a suit against the builder of a swimming pool); S. Kornblum Metals Co. v. Intsel Corp., 47 App. Div. 2d 523, 362 N.Y.S.2d 568 (1975), discussed in note 37 supra; C.M.I. Clothesmakers, Inc. v. A.S.K. Knits, Inc., 85 Misc. 2d 462, 380 N.Y.S.2d 447 (Sup. Ct. 1975), discussed in text at note 45 infra; Centennial Ins. Co. v. Tanny Intl., 46 Ohio App. 2d 137, 346 N.E.2d 330 (1975) (inadequate discussion of the applicability of article 2 to sauna room and heater installed in health spa). 
pretation of the Code. $\operatorname{Six}^{42}$ were so classified because it appeared that the court may have overreacted to a claim's obvious lack of merit or may have been influenced by the size and sophistication of the plaintiff or the defendant. For example, the.New York court in Sears, Roebuck \& Co. v. Enco Associates ${ }^{43}$ might have been more willing to consider the extension by analogy of warranty liability to an architect had the plaintiff been someone other than Sears and had it suffered something other than a relatively modest loss. That contention is supported by the New York application of warranty liability to a lease transaction in the Owens ${ }^{44}$ case, another one of the 11 cases that were not guidesome. To the extent that the "non-guidesome" cases arise out of the noncommercial warranty area, the drafters cannot be blamed (except of course for not somehow excluding that area from the Code), for there is no way to force a court honestly to articulate a premise that it is unwilling to defend publicly.

Other non-guidesome cases should be a source of concern to legislative drafters. An example is C. M. I. Clothesmakers, Inc. $v$. A. S. K. Knits, Inc., ${ }^{45}$ in which the court did not adequately distinguish between sections $2-201$ on the requirement of a writing and 2-207 on contract formation. The presence of a memorandum may satisfy the Statute of Frauds, but it does not establish the terms of the contract when the memorandum is to be supplemented by other memoranda, acknowledgements, or oral agreements. In $C . M$. I. the

42. See Becker v. Volkswagen of America, 52 Cal. App. 3d 794, 125 Cal. Rptr. 326 (1975) (disbelief of claim three and one-half years after automobile accident that leaking fuel vapors were the cause of the accident); Dorman v. International Harvester Co., 46 Cal. App. 3d 11, 120 Cal. Rptr. 516 (1975) (relative size of parties influenced decision to reject an apparently adequate disclaimer of warranty); Gantry Constr. Co. v. American Pipe \& Constr. Co., 49 Cal. App. 3d 186, 122 Cal. Rptr. 834 (1975) (decision reversing $\$ 31 / 2$ million slander judgment awarded by jury as a result of a statement that seemed correctly to reflect upon plaintiff's creditworthiness); Owens v. Patent Scaffolding Co., 50 App. Div. 2d 866, 376 N.Y.S.2d 948 (1975) (solicitude toward injured plaintiff); Curtis v. Fordham Chrysler Plymouth, Inc., 81 Misc. 2d 566, 364 N.Y.S.2d 767 (Civ. Ct. 1975) (disbelief of claim that problems with new automobile justified action for price); Sears, Roebuck \& Co. v. Enco Assocs., 83 Misc. 2d 552, 370 N.Y.S.2d 338 (Sup. Ct. 1975), affd., 54 App. Div. 2d 13, 385 N.Y.S.2d 613 (1976) (relative size of parties and type of injury influenced decision not to extend warranty protection).

43. 83 Misc. 2d 552, 370 N.Y.S.2d 338 (Sup. Ct. 1975), affd., 54 App. Div. 2d 13, 385 N.Y.S.2d 613 (1976). See notes $37 \& 42$ supra.

44. Owens v. Patent Scaffolding Co., 50 App. Div. 2d 866, 376 N.Y.S.2d 948 (1975). The plaintiff in this case sustained personal injuries in the use of rented scaffolding equipment. The court applied the six-year statute of limitations for contracts in general rather than the shorter four-year limitation of the Code even though the Code's warranty provisions were applied by analogy.

45. 85 Misc. 2d 462, 380 N.Y.S.2d 447 (Sup. Ct. 1975). 
court appeared to conclude that compliance with section 2-201(2) on the statute of frauds renders a term in the complying document part of the contract.

However, one must give the drafters credit for section 2-302 on unconscionability. A comparison of California and New York decisions in Table 2 suggests the importance of that section. Presumably each of the fourteen courts in New York that cited section 2-302 had the "real issues" before it and discussed those issues in a candid way - whether or not the court came to a correct conclusion. Presumably similar cases in similar numbers also arose in California and were dealt with by the courts under other rubrics. Conceivably those who would successfully assert section 2-302 in New York are defeated in California, but one doubts that all or even most are. If most are successful in avoiding unconscionable contracts on some ground other than unconscionability, the use of the "covert tools" that Llewellyn detested is growing in the California law. ${ }^{48}$

\section{Application by Analogy}

A final argument in favor of article 2's significance might be that it has had a powerful, salutary influence on non-Code law. Sometimes courts have unknowingly applied damage sections of article 2 to cases apparently outside the article's scope. ${ }^{47}$ In other cases the

46. Section 2-302 was raised in six of the 1975 Code cases from New York. Three of these cases dealt with the sale of goods, and in one the argument was successful. See Brooklyn Union Gas Co. v. Jimeniz, 82 Misc. 2d 948, 371 N.Y.S.2d 289 (Civ. Ct. 1975) (contract for sale of gas burner unconscionable in seller's action for price, where seller found to have used high-pressure sales tactics on a Spanishspeaking buyer). But see Lincoln First Natl. Bank v. Grabowski, 50 App. Div. 2d 1074 , 376 N.Y.S.2d 342 (1975) (conditional sales contract and insurance policy to cover payment not unconscionable where insurer disclaimed liability for pre-existing disability pursuant to the terms of the policy); Curtis v. Fordham Chrysler Plymouth, Inc., 81 Misc. 2d 566, 364 N.Y.S.2d 767 (Civ. Ct. 1975) (claim of unconscionable warranty limitation denied where plaintiff car buyer failed to prove any measure of damages; see also notes 31 \& 42 supra).

In one case not involving a sale of goods, the court appeared to apply $\S 2-302$ but found that the contract was not unconscionable. See In re Estate of Young, 81 Misc. 2d 920, 367 N.Y.S.2d 717 (Sur. Ct. 1975) (publishing contracts which limited author's royalty payments to $\$ 3,000$ per year held not unconscionable in action by author's estate to collect $\$ 58,000$ royalties earned).

The remaining two cases rejected the application by analogy of $\S 2-302$, although one court found a contract provision unconscionable as a matter of equity. See Bankers Trust Co. v. Walker, 49 App. Div. 2d 670, 371 N.Y.S.2d 198 (1975) (application of $\S 2-302$ to surety contract rejected). Cf. Weidman v. Tomaselli, 81 Misc. 2d 328, 365 N.Y.S.2d 681 (Sup. Ct.), affd. mem., 84 Misc. 2d 782, 386 N.Y.S.2d 276 (App. Term 1975) (lease clause providing for tenant's payment of $\$ 100$ attorney's fees upon commencement of any proceeding instituted by landlord against tenant held unconscionable in equity; analogy of landlord to a seller bound by $\$ 2-302$ was explicitly rejected).

47. See Coast Indus. v. Noonan, 4 Conn. Cir. Ct. 33, 231 A.2d 663 (1967) (applying $\$ 2-708$ to a construction contract). 
courts have by analogy applied unconscionability doctrines or the warranty rules to transactions not involving the sale of goods. ${ }^{48}$ Moreover, it is likely that at least more sophisticated judges and lawyers have applied doctrines set out explicitly in the Code to other areas of the law without reference to the Code. For example, the Code's rules on trade usage, the Statute of Frauds, and various priority rules have doubtless had an unrecognized or unacknowledged impact on case law not involving the sale of goods.

It was our hope to measure the Code's impact as a tool for analogy by finding cases in which article 2 was applied by analogy and by determining how it was applied. ${ }^{49}$ Of course, any case in which article 2 was applied without specific reference to the Code would not have been found in our diggings. Table 6 shows a one-year segment of Sales Act and Uniform Commercial Code cases in which at least one party argued for the application of the Code or the Sales Act by analogy.

TABLE 6

Application by ANalogy of USA and UCC CASES

\begin{tabular}{ccr}
\hline Analogy & USA & UCC \\
\hline Yes & $2(11.8 \%)$ & $8(19.5 \%)$ \\
\hline No & $15(88.2 \%)$ & $33(80.5 \%)$ \\
\hline
\end{tabular}

Although the percentages might appear to indicate a potentially greater application of article 2 by analogy than occurred with the Sales Act, a closer examination of the data does not necessarily support that conclusion. Of the eight cases under the Code in which one party argued for its application by analogy, ${ }^{50}$ one is from Ohio,

48. See, e.g., United States Leasing Corp. v. Franklin Plaza Apts., 65 Misc. 2d 1082, 3.19 N.Y.S.2d 531 (Civ. Ct. 1971) (unconscionability applied to lease of equipment); Electronics Corp. of America v. Lear Jet Corp., 55 Misc. 2d 1066, 286 N.Y.S. 2d 711 (Sup. Ct. 1967) (unconscionability applied to lease of equipment); Hertz Commercial Leasing Corp. v. Transportation Credit Clearing House, 59 Misc. 2d 226, 298 N.Y.S.2d 392 (Civ. Ct. 1969) (warranties applied to lease of equipment) revd. on other grounds, 64 Misc. 2d 910, 316 N.Y.S.2d 585 (Sup. Ct. 1970).

49. Determining whether application was by analogy was sometimes difficult. See, e.g., Lincoln First Natl. Bank v. Grabowski, 50 App. Div. 2d 1074, 376 N.Y.S.2d 342 (1975) (involving the possible application of article 2 to an insurance contract accompanying a sales contract for an automobile).

50. See Black v. Sullivan, 48 Cal. App. 3d 557, 122 Cal. Rptr. 119 (1975); Owens v. Patent Scaffolding Co., 50 App. Div. 2d 866, 376 N.Y.S.2d 948 (1975); Owens v. Palm Tree Nursing Home, Inc., 50 App. Div. 2d 865, 376 N.Y.S.2d 946 (1975); Bankers Trust Co. v. Walker, 49 App., Div. 2d 670, 371 N.Y.S.2d 198 (1975); Sears, Roebuck \& Co. v. Enco Assocs., 83 Misc. 2d 552, 370 N.Y.S.2d 338 (Sup. Ct. 1975), affd., 54 App. Div. 2d 13, 385 N.Y.S.2d 613 (1976); In re Estate of Young, 81 
one is from California, and the other six are from New York. In five of those cases the courts flatly rejected application of the Code to the particular facts at hand. ${ }^{51}$ In another case the court appeared to apply section 2-302 but concluded that the contract was not unconscionable. $^{52}$ In only one case did application of the Code by analogy produce a different result than might otherwise have occurred. ${ }^{63}$ Moreover, since all eight cases are either section 2-302 or warranty cases, they give no support to the argument that the Code is serving as a model for the development of our commercial law beyond sales transactions. Although the sample of cases is small and thus inconclusive, the evidence does show that if the Code is influencing the non-Code commercial law in an extensive way, that influence is not widely articulated in the cases.

\section{CONCLUSION}

This article was stimulated by a recent reading of the CarterField codification debates in New York, ${ }^{54}$ by reconsideration of some of the writings of Llewellyn ${ }^{55}$ and Frank ${ }^{56}$ on legal realism, and finally by Eaton's 1913 article. ${ }^{57}$ In one way or another each of those writers touches upon the utility and the function of a code. Carter

Misc. 2d 920, 367 N.Y.S.2d 717 (Sur. Ct. 1975); Weidman v. Tomaselli, 81 Misc. 2d 328, 365 N.Y.S.2d 681 (Sup. Ct.), affd. mem., 84 Misc. $2 \mathrm{~d} 782$, 386 N.Y.S.2d 276 (App. Term 1975); Brown v. Christopher Inn Co., 45 Ohio App. 2d 279, 344 N.E.2d 140 (1975).

51. Bankers Trust Co. v. Walker, 49 App. Div. 2d 670, 371 N.Y.S.2d 198 (1975), briefly discussed in note 46 supra; Sears, Roebuck \& Co. v. Enco Assocs., 83 Misc. 2d 552, 370 N.Y.S.2d 338 (Sup. Ct. 1975), affd., 54 App. Div. 2d 13, 385 N.Y.S.2d 613 (1976), discussed in note 37 supra; Weidman v. Tomaselli, 81 Misc. 2d 328, 365 N.Y.S.2d 681 (Sup. Ct.), affd. mem., 84 Misc. 2d 782, 386 N.Y.S.2d 276 (App. Term 1975); discussed in note 46 supra; Brown v. Christopher Inn Co., 45 Ohio App. 2d 279, 344 N.E.2d 140 (1975) (in action for value of items stolen from automobile in hotel parking lot, article 2 warranty provisions held inapplicable to an employee's guarantee of parking lot security); Owens v. Patent Scaffolding Co., 50 App. Div. 2d 866, 376 N.Y.S.2d 948 (1975), discussed in note 32 supra.

52. In re Estate of Young, 81 Misc. 2d 920, 367 N.Y.S.2d 717 (Sur. Ct. 1975), discussed in note 46 supra.

53. Owens v. Patent Scaffolding Co., 50 App. Div. 2d 866, 376 N.Y.S.2d 948 (1975), discussed in note 32 supra.

54. See J. Carter, The Proposed Codification of Our Common law (1884); D.D. FIELD, supra note 5.

55. See the following articles written by Llewellyn: Across Sales on Horseback, 52 HARV. L. REv. 725 (1939); The First Struggle to Unhorse Sales, 52 HARV. L. REV. 873 (1939); On Reading and Using the Newer Jurisprudence, 40 CoLUM. L. REv. 581 (1940); Some Realism About Realism-Responding to Dean Pound, 44 Harv. L. REv. 1222 (1931).

56. See J. FranK, Law and the Modern Mind (6th Printing 1949).

57. See Eaton, note 1 supra. 
and Field are passionate advocates of opposing points of view; Frank seems quite cynical of the power of any code to harness a spirited and clever judiciary; Llewellyn is a paradoxical mixture of legal realist and codifier extraordinaire.

Considering those writings, one concludes that the quality of our law, both statutory and otherwise, may be improving, but that the depth of our analysis and the sophistication of our measurements of the quality of law is not. Too often modern arguments about the nature and function of codified law simply recapitulate the CarterField debates.

The sample of cases produced by our diggings is probably too small to give anything but a gross indication of article 2's impact and quality. The principal function of this piece is to test the proposition that quality and impact can be objectively measured and to make a preliminary attempt at such measurement. Though others will conceive more sophisticated and objective tests of justness and correctness, the results of our admittedly crude and rather limited tests should lead one to be skeptical about the possible impact of even an elaborate and widely adopted commercial statute.

The next step might be the application of a more sophisticated test to a larger number of cases. A yet more ambitious project would be to dig deeper into the legal process and measure the ways in which a commercial code affects law office work in commercial planning and in handling non-litigated disputes. Ultimately, if we cannot improve upon the intuitive judgments of Field and Carter, now more than 75 years old, perhaps we should conclude that commercial statutes have so little impact upon the behavior of courts, lawyers, and laymen that our attention must turn to other things. 